\title{
Deprived Sector Lending and Non-Performing Loans in Nepal
}

\author{
Sudan Kumar Oli ${ }^{1}$ \\ ${ }^{1} \mathrm{PhD}$ candidate, School of Insurance and Economics, University of International Business and Economics, Beijing, \\ 100029, China
}

Correspondence: Sudan Kumar Oli, School of Insurance and Economics, University of International Business and Economics, Beijing, 100029, China.

\author{
Received: June 15, 2021 \\ Accepted: July 2, $2021 \quad$ Available online: July 9, 2021 \\ doi:10.11114/aef.v8i4.5261 \\ URL: https://doi.org/10.11114/aef.v8i4.5261
}

\begin{abstract}
This study investigates the empirical impact of deprived sector lending on the nonperforming loans of commercial banks in Nepal using secondary data collected from 27 commercial banks from the fiscal year 2009 to 2018 with 262 observations. The study employed the OLS regression method for the robustness test of the result. The study establishes empirical relation between deprived sector lending and nonperforming loan of banks which was the major motivation of this study. The basic regression result shows that beta coefficient of DSL is negative which indicates higher the ratio of deprived sector lending, the lower would be the NPL and vice-versa. Similarly, this study also examines the DSL movement's impact on NPL. The result shows that the beta coefficient of $\triangle \mathrm{DSL}$ is significantly negative with $\triangle \mathrm{NPL}$. This indicates that the higher the growth of DSL, the lower would be NPL growth and vice-versa. This shows that the influence of DSL is very low as per this empirical result. Overall, the study shows there is an inverse relationship between deprived sector lending and nonperforming loan of banks. The result indicates that the remark of commercial bank's on the deprived sector lending policy of NRB is not true. The operational cost might increase with direct lending to deprive sector and that leads to decrease in the bank's overall profit but not increases their NPL.
\end{abstract}

Keywords: deprive sector lending, nonperforming loan, NRB policy, bank risk and empirical relation

\section{Introduction}

Bank and financial institutions are the major players in capital mobilization in the economy. The banking sector is the most regulated sector after the recent financial crisis of 2007/8. The banking institution is the most sensitive and responsible sector because it holds a large size of public deposits. The central bank of the country holds the regulatory position and introduces credit policy to control misuse of public funds and smooth operations in a sound environment. The global financial crisis of 2008 had pushed to the revolving nature of credit lending and the tendency of financial institutions to take high-risk associated assets during the credit upturns in advanced economics (Gambacorta and Chavan, 2019). Credit risk is a major risk of commercial banks, hence, measurement, control, and management of credit risk is the core task of risk management. The risk of commercial banks mainly indicates by the accumulation size of non-performing loans (Tang, et al., 2009).

Nepal Rastra Bank (NRB) has introduced provisions relating to lending in the deprived sector through directive 17/067. NRB directive number 17/067 defines the deprived as low income and especially socially backward women, tribal people, Dalit, blind, hearing impaired and physically incapacitated persons, marginalized and small formers, craft-men, labor, and landless squatters families. As per directive 17/067, the "A", "B", and "C" class licensed institutions needed to lend at least 3 percent, 2 percent, and 1.5 percent of the total outstanding loans and advances respectively. Now, all ("A", "B", and "C") class license holding institutions have required to flow at least 5 percent of total outstanding lending and advances mandatorily (Monetary Policy FY 2018/19).

Previously, banks were lending to the deprived sectors in collaboration with microfinance institutions. But after the Monetary Policy 2016/17, commercial banks should have to lend deprived sector themselves at least 2 percent and remain 3 percent should flow in collaboration with microfinance institutions. Due to this provision, banks are being afraid of increasing operational costs and nonperforming assets. According to Nepal Bankers' Association (NBA), direct lending to the deprived sector by commercial banks will increase the non-performing assets. This claim of the NBA is similar to the study of Reddy (2004) which concludes that the priority sector is creating more NPAs for the banking sector. The study finding of Reddy (2009) is also supported by Kadanda and Raj (2018). Moreover, 
commercial banks have to provide a semi-annual progress report of the utilization of extended deprived sector's credit through wholesale credit institutions. If the regulatory body found the misused of such a credit facility, they are liable to pay a penalty.

A non-performing loan (NPL) is a sum amount of borrowed money in which the debtor has not made the scheduled payments for a specified period. NPL indicates the quality of assets of the banks. As per central bank regulation banks should be made a provision against NPL prescribed by NRB. This study is focusing on the issue of whether the deprived sector lending increases the bank's risk or not.

According to the Bank Supervision Report (2018), the total volume of nonperforming loans of the commercial banks increased by $8.14 \%$ in the fiscal year 2017/18 and reached NPR.29.85 billion. The NPL of private-owned banks increased by 8.27 percent to NPR.18.25 billion and public sector banks increased by 7.93 percent to NPR.11.63 billion. However, the NPL ratio decreased from 1.67 percent to 1.49 percent during the review period. Even the Indian banking sector have also a similar story. Overall, the NPLs of the private sector banks are significantly lower than those of the public sector banks in India (Sinha, 2012).

Nepal has made a deprived sector lending policy separately. But other economies do not have a separate policy for deprived sector credit. They have made a provision of priority sector lending and included all the areas as microfinance lending. In India, the priority sector refers to those sectors of the economy which though viable and creditworthy may not get in time and adequate amount of credit in the absence of this special dispensation. This is a small valued loan to farmers for agriculture and allied activities, micro and small enterprises, poor people for housing, students for education, and other low-income group and weaker sections of the economy (Oli, 2018). Banks should provide credit directly to beneficiaries instead of rotating loans within intermediaries which will ensure better management of risk and reduce the intermediate cost of loans (Deokar and Shetty, 2013).

This paper has tried to figure out few bank-specific variables which impact NPL along with deprived sector lending policy such as bank sizes, ownership structure, net interest income, market shares as control variables. This study has employed nonperforming loans (NPL) as a proxy of risk indicator because NPL is the good measure of the level of bad credits of the lending institutions.

\section{Why deprived sector lending is important?}

As per the economic survey 2017/18 issued by the Government of Nepal, Ministry of Finance, 21 percent of people are living below the poverty line which was 42 percent in 1996. The major root cause of poverty is the lack of financial resources access to fulfil initial capital and promote entrepreneurship. The bank and financial institutions are the prime sources of financial resources which channelize fund from surplus unit to shortage. These institutions play a role to mobilize the financial resources across the economy. It is believed that access to financial resources activated indigenous skills and increases the productivity of the poor and marginalized people. To address this issue NRB introduced the directed credit policy which is called the deprived sector credit policy and aimed to help to flourish the micro and local economic activities in the country and help to poverty alleviation target of the government.

\section{Mandatory policy provision}

NRB issued directives to commercial banks for a certain percent of compulsory lending to deprived people in 1990 for the first time. The banks and financial institutions should be penalized for any shortfall in the prescribed amount of deprived sector lending. The government of Nepal has been providing interest subsidies on deprived lending through the fiscal policy in F.Y.1996/97. The following table shows the deprived sector lending provision for commercial banks over the period of its initiation.

Table 1. Commercial banks' deprived sector lending provision by NRB

\begin{tabular}{|cccc|}
\hline 1990 & 2008 & 2009 & 2018 \\
\hline $3 \%$ & $3 \%$ & $3 \%$ & $5 \%$ \\
\hline
\end{tabular}

Source: NRB Directives and monetary policies

Monetary Policy 2016/17 has provisioned two percent of direct lending to the deprived sectors out of five percent in total credit. As per the provision each commercial bank has to lend directly to the deprived sector and commercial banks should expand their branch and networks to rural areas which leads to an increase in operational costs (Nepal Bankers' Association, 2016/17). 


\section{Deprived sector lending status of banks}

In order to achieve the sustainable economic growth of the country, NRB has been endeavoring to extend financial access and inclusion through various incentives directed towards banks and financial institutions (Financial Stability Report, 2018). As per the monetary circular, commercial banks, development banks, and finance companies must flow 5 percent of total credit to the deprived sectors. The deprived sector covered the untapped and marginalized areas where regular or mainstream financial service access has not reached.

According to the report, the financial policy of establishing a branch of commercial banks in every local level of government should gradual increment in deprived sector lending requirement for licensed banks and financial institutions (BFIs), mandatory requirements for them to invest a certain percentage of their total credits. The overall deprived sector lending by commercial banks as of mid-July 2018 is 5.94 percent. The given figure illustrates the last 7 year's deprived sector lending by commercial banks.

Table 2. deprived sector lending by commercial banks

\begin{tabular}{|c|c|c|c|c|c|c|}
\hline $\mathbf{2 0 1 2}$ & $\mathbf{2 0 1 3}$ & $\mathbf{2 0 1 4}$ & $\mathbf{2 0 1 5}$ & $\mathbf{2 0 1 6}$ & $\mathbf{2 0 1 7}$ & $\mathbf{2 0 1 8}$ \\
\hline 3.8 & 4.3 & 5.2 & 5.1 & 5.52 & 5.95 & 5.94 \\
\hline
\end{tabular}

Source: NRB Financial Stability Reports/Respective Commercial Bank’s Reports

This study is motivated by two elements and proposes their empirical investigation. First, the lack of empirical evidence concerning the impact of deprived sector lending on bank credit risk. Secondly, the lack of evidence on the relationship of deprived sector lending on nonperforming loans. Therefore, the major objective of this study is to investigate the role of deprived sector lending on nonperforming loans of commercial banks in Nepal. This study also tries to investigate the impact of deprived sector lending on banks' performance.

In addition to the introduction section, this study has been organized into major five sections. Section two contains a literature review that provides basic ideas and the conceptual framework of the study. Section four contains data and methodologies specifications for the study. Similarly, section five illustrates major data analysis results. And final section six summarizes the results and draws an important conclusion from this study.

\section{Literature Review}

This section reviewed the literature of previous studies. The literature review has been a focus on two basic areas; review related to non-performing loan and bank-specific variables and deprived sector lending and its impacts on bank performance and risks. Attention has paid to empirical models, data used, and key findings of the study during the review.

Aynalem (2016) investigates the factor affecting nonperforming loans of commercial banks of Ethiopia during the period from 2002 to 2015 using a multiple linear regression equation. The study result indicates that among the studied variables, loan to deposit ratio, return on equity, and capital adequacy were found to be a statistically significant determinant of NPLs. On the other hand, bank size was statistically insignificant in affecting NPL. Pepur and Tripovic (2017) state that the banks are exposed to a wide range of different risks and credit risk is considered one of the most important and most influential ones in terms of affecting banks' performance. To investigate credit risk and profitability relationship, a dynamic panel data analysis model was applied with data set of commercial banks from the period of 2003 to 2013.

Deokar and Shetty (2013) investigate the extent and growth of NPAs and interbank disparity in NPA management among public sector banks. The study employed a dynamic panel data technique for estimations with the data period from March 2009 to March 2017 resulting in 189 firms' year observations. Berger and Deyoung (1997) argue that banks with relatively lower capital have moral hazard incentives by taking excessive risk in their loan portfolio resulting in higher NPA in the following years by using Granger-causality techniques to test four hypotheses. Sharma (2005) argues that growing NPA harms not only the profitability of the banks but also adversely affects the entire economy by disturbing the smooth flow of credit to various sectors of the economy. They found that NPA affects key variables like profitability, business per employee, profit per employee interest spread, and capital adequacy. Similarly, Kaur (2012); Dhar and Bakshi (2015); Verma and Bodla (2006), and Bhatia et al. (2012) also supported the negative relationship between NPA and bank profitability.

Jouida (2019) employed the Panel data Vector Auto Regression (PVAR) methodology to examine the simultaneous multi-directional relationship between bank capital structure, capital ratio, and SRIPK. PVAR method represents a hybrid econometric methodology that combines the traditional VAR approach which considers all variables in the structure as endogenous, with panel data technique which allows for explicit inclusion of a fixed effect in the model 
which was also used by Canova and Ciccarelli (2013). The conventional VAR model was first introduced by Sims (1980) and use to examine the time series property of each variable via the panel unit-root test. Sufian and Habibullah (2009) examine the determinants of the profitability of the Chinese banking sector during the post-reform period of 2000-2005. The result suggested that liquidity, credit risk, and capitalization have positive impacts on the state-owned commercial bank's profitability. Using regressions on aggregate data for the period 2001-2012, Lokare (2014) found statistical evidence for a positive response of NPLs to the credit to GDP ratio lagged up to 1 year.

Gambacorta and Chavan (2019) estimate dynamic specification that includes one lagged value of the NPL ratio as an explanatory variable. The study use data on gross NPLs as the dependent variables. The study test for the possible presence of structural breaks in the baseline model on accounts of the global financial crisis. They used dummy crises that take the value of 1 for the period 2009 to 2014 and zero otherwise and interact it with all the variables in the model. For the robustness test regression was carried out using a Dynamic Panel Data (DPD) model based on Generalized Method of Moments (GMM) which is suitable for the analysis of lagged dependent variables and endogenous factors that may be correlated with the past/current realization of the error term. The variables are tested for stationarity using the panel unit root tests.

Bruton et al. (2011) employed qualitative case studies development method in Guatemala and the Dominican Republic and concluded that high performance and business failure for microloan recipients. Furfine (2001) develops a structural dynamic model of the banking firms to analyze how bank adjust their loan portfolio over time by using panel data. The simulation results are used to shed light on the decline in loan growth and the rise in bank capital ratio.

\section{Conceptual Framework}

Based on the above literature review and rationality of the study context, this study has used nonperforming loans (NPL) as a proxy of banks' credit risk or quality of bank credits. Previous studies such as Pepur and Tripovic (2017); Verma and Bodla (2006); and (Sinha, 2012) also used nonperforming assets as indicators of the credit quality of banks. This study has been employed deprived sector lending as the central independent variable to explain nonperforming loans. Especially, private sector banks are arguing that deprived sector lending will be pressurized on NPLs. But if we look back to the social norms and tradition, deprived sector loans will not be a problem for banks due to their prestige and trust.

Therefore, the study has tried empirically to investigate whether DSL really leads to NPLs or not. Besides DSL this study incorporates a few other banks' specific variables such as bank size, net interest income, ownership structure, risk-weighted average capital ratio, and market coverage of bank. Figure 1 shows the basic conceptual framework of the study.

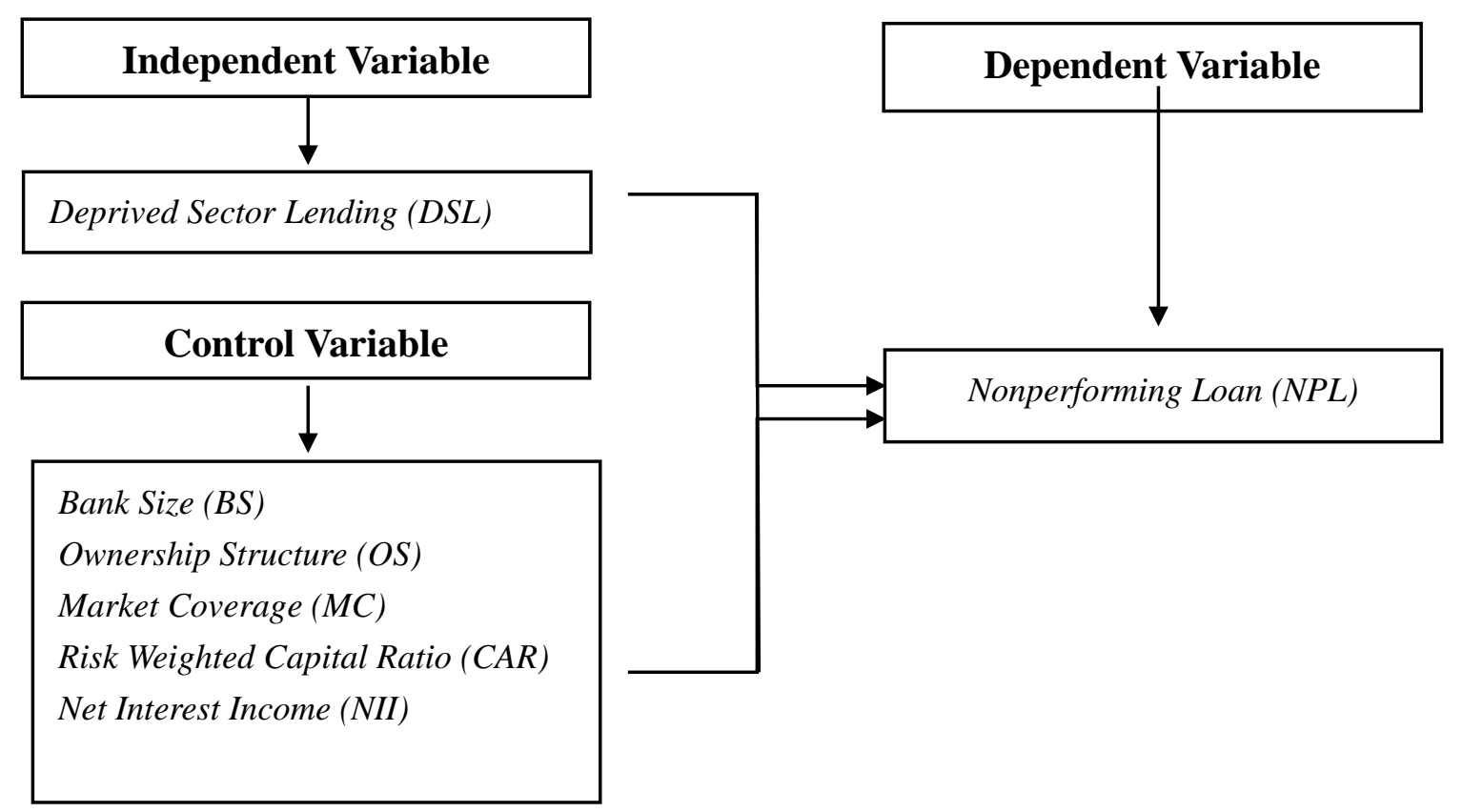

Figure 1. Conceptual framework 
For the empirical analysis of deprived sector lending's influence on a bank's nonperforming loan, bank-specific variables will be used as the control variables. This study will not use any macroeconomic variables. Therefore, the major limitation of the study is the concentration only on derived sector lending and nonperforming loan excluding other associated factors.

\section{Data and Methodology}

\subsection{Data}

This study is based on secondary data collected from the annual reports of respective banks, Banking, and Financial Statistics reports, and Bank Supervision Reports published by Nepal Rastra Bank. The data have been collected from 27 banks out of 28 commercial banks in Nepal from the fiscal year 2009 to 2018. Prabhu Bank Limited has been excluded from the study because of data. This bank was introduced after the merger with Kist Bank Limited. Table 3 shows the list of the commercial banks selected for the study along with the study period and number of observations respectively.

Table 3. List of the Commercial banks selected for the study along with study period and number of observations

\begin{tabular}{|c|c|c|}
\hline Name of Bank & Study Period & No. of Observations \\
\hline Nepal Bank Limited & $2009-2018$ & 10 \\
\hline Rastriya Banijya Bank & $2009-2018$ & 10 \\
\hline Nabil Bank Limited & $2009-2018$ & 10 \\
\hline Nepal Investment Bank & $2009-2018$ & 10 \\
\hline Standard Chartered bank Nepal & $2009-2018$ & 10 \\
\hline Himalyan Bank Limited & $2009-2018$ & 10 \\
\hline Nepal SBI Bank Limited & $2009-2018$ & 10 \\
\hline Nepal Bangladesh Bank & $2009-2018$ & 10 \\
\hline Everest Bank Limited & $2009-2018$ & 10 \\
\hline Bank of Kathmandu Limited & $2009-2018$ & 10 \\
\hline NCC Bank Limited & $2009-2018$ & 10 \\
\hline NIC Asia Bank Limited & $2009-2018$ & 10 \\
\hline Machapuchhre Bank Limited & $2009-2018$ & 10 \\
\hline Kumari Bank Limited & $2009-2018$ & 10 \\
\hline Laxmi Bank Limited & $2009-2018$ & 10 \\
\hline Siddhartha Bank Limited & $2009-2018$ & 10 \\
\hline Agriculture Development Bank Limited & $2009-2018$ & 10 \\
\hline Global IME Bank Limited & $2009-2018$ & 10 \\
\hline Citizen Bank Int'l Limited & $2009-2018$ & 10 \\
\hline Prime Commercial Bank Limited & $2009-2018$ & 10 \\
\hline Sunrise Bank Limited & $2009-2018$ & 10 \\
\hline NMB Bank Limited & $2009-2018$ & 10 \\
\hline Janata Bank Limited & $2009-2018$ & 10 \\
\hline Megha Bank Limited & $2011-2018$ & 8 \\
\hline Civil Bank Limited & $2011-2018$ & 8 \\
\hline Century Bank Limited & $2011-2018$ & 8 \\
\hline Sanima Bank Limited & $2010-2018$ & 8 \\
\hline+2 & & 262 \\
\hline
\end{tabular}

(Source: www.nrb.org.np and respective banks websites)

Thus the study is based in 262 observations.

\subsection{Model Specification}

This study has been employed ordinary least squire (OLS) regression analysis. To analyze the impact of deprived sector lending on a nonperforming loan of the commercial banks following basic model has been estimated.

\section{Model-1}

$(\mathrm{NPL})_{\mathrm{it}}=\boldsymbol{\beta}_{0}+\boldsymbol{\beta}_{1}(\mathrm{DSL})_{\mathrm{it}}+\boldsymbol{\beta}_{2}(\mathrm{BS})_{\mathrm{it}}+\boldsymbol{\beta}_{3}(\mathrm{MC})_{\mathrm{it}}+\boldsymbol{\beta}_{4}(\mathrm{OS})_{\mathrm{it}}+\boldsymbol{\beta}_{5}(\mathrm{CAR})_{\mathrm{it}}+\boldsymbol{\beta}_{6}(\mathrm{NIN})_{\mathrm{it}}+\boldsymbol{\phi}_{\mathrm{it}}+\varepsilon_{\mathrm{it}}$ Where,

$N P L=$ Nonperforming loans

$D S L=$ Deprived sector lending

$B S=$ Banks size

$M C=$ Market share

$O S=$ Ownership structure 


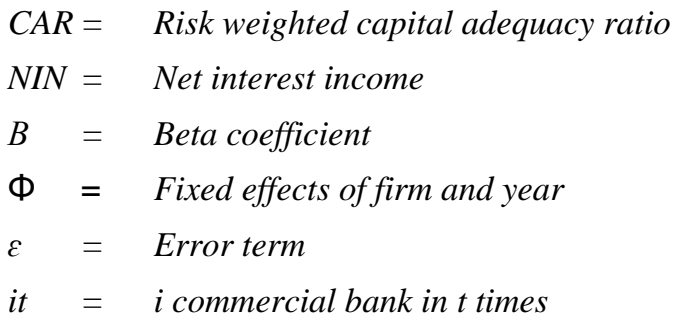

This study is centralized with DSL. This linear regression analysis will give a general idea about the impact of DSL on NPL. Besides that, I also try to use another test to check on the movement of DLS and NPL by using the changing rate of DSL and NPL. This model removed CAR from the control variables. The basic model has listed the above-mentioned control variables but they are just the purpose of model estimation. The result analysis will be completely based on DLS.

\section{Model-2}

$(\Delta N P L)_{i t}=\beta_{0}+\beta_{1}(\Delta D S L)_{i t}+\beta_{2}(\Delta B S)_{i t}+\beta_{3}(\Delta M C)_{i t}+\beta_{4}(O S)_{i t}+\beta_{5}(\Delta N I N)_{i t}+\phi_{i t}+\varepsilon_{\text {it }}$

In this model, $\triangle \mathrm{NPL}$ is the change in nonperforming loans of commercial banks and $\triangle \mathrm{DSL}$ is the change in deprived sector lending. All other variables are defined as the same in equation 1 except the addition of changes $(\Delta)$ on each. This model has used for the directional robustness test of the DSL and NPL.

Table 4. shows the summarized definitions of all the variables selected for the study.

Table 4. Definitions of the variables

\begin{tabular}{|l|l|l|}
\hline \multicolumn{1}{|c|}{ Symbols } & \multicolumn{1}{c|}{ Variables } & \multicolumn{1}{c|}{ Descriptions } \\
\hline NPL & Nonperforming Loan & $\begin{array}{l}\text { Ratio of default loan classified under nonperforming loan in } \\
\text { percentage. }\end{array}$ \\
\hline DSL & Deprived Sector Lending & Ratio of total deprived sector lending out of total loan in percentage. \\
\hline BS & Bank Size & Natural logarithm of total assets of the firms \\
\hline MC & Market Coverage & Number of branches operating all over the country \\
\hline OS & Ownership Structure & $\begin{array}{l}\text { Ownership structure represents the dummy variable indicating 1 for } \\
\text { public bank and 0 otherwise. }\end{array}$ \\
\hline CAR & Capital Adequacy Ratio & Risk weighted capital adequacy ratio of bank in percentage \\
\hline NII & Net Interest Income & Natural logarithm of net interest income. \\
\hline
\end{tabular}

\section{Result and Discussion}

\subsection{Descriptive Statistics}

The descriptive statistics of dependent variables (NPL) and independent variables (DSL, BS, MC, CAR, and NII) have been presented in Table 5.1. The descriptive statistics include minimum, maximum, mean, and standard deviation. The study takes NPL as the proxies to measure the bank's credit risk.

Table 5. Descriptive summary statistics of data used for the study

This table shows the descriptive statistics of dependent and independent variables. The dependent variable is nonperforming loan (NPL in percentage). The independent variables are deprived sector lending (DSL in percentage), bank size (total assets in NPR. Million), market coverage (MC in number of branches operating all over the country), capital adequacy ratio (CAR in percentage), and net interest income (NII in NPR. Million).

\begin{tabular}{|c|c|c|c|c|}
\hline \multicolumn{5}{|c|}{ Descriptive Statistics } \\
\hline & Minimum & Maximum & Mean & Std. Deviation \\
\hline Nonperforming Loan $(\%)$ & 0.00 & 19.30 & 1.94 & 2.48 \\
\hline Deprived Sector Lending (\%) & 0.00 & 11.89 & 4.55 & 1.40 \\
\hline Bank size (Total assets in NPR. Millions) & $2,365.60$ & $197,332.0$ & $58,118.82$ & $40,015.59$ \\
\hline Market Coverage ( No. of Branches) & 3.00 & 250.00 & 57.74 & 49.14 \\
\hline Capital Adequacy Ratio (\%) & 37.70 & 67.81 & 12.61 & 7.60 \\
\hline Net Interest Income (In NPR. Millions) & 42.00 & $9,114.23$ & $1,853.24$ & $1,514.55$ \\
\hline
\end{tabular}

Source: Writer's own calculation using SPSS V.23.

Table 5 shows that nonperforming loan of bank ranges from 0.00 to 19.30 percent with an average of 1.94 percent. Likewise, deprived sector lending ranges from 0.00 to 11.89 percent along with an average of 4.55 percent. The total asset of the bank ranges from the minimum of NPR. 2365.60 million to maximum of NPR.197332 million with an 
average of NPR.5811882 million. Similarly, the number of branches ranges from 3 to 250 with an average of 58 branches operating all over the country. The risk-weighted average capital adequacy ratio of banks ranges from -37.70 to 67.81 percent along with an average of 12.61 percent. Likewise, the net interest income of banks ranges from NPR.42 million to NPR. 9,114.23 million with an average amount of NPR.1, 853.24 million.

\subsection{Correlation Analysis}

The correlation analysis result gives the interconnection and directional association of variables with each other. Thus, this section provides the results and discussions of Pearson's correlation analysis for the study. Table 5.2 represents the correlation coefficients for the variables.

Table 6. Pearson's Correlations coefficient

This table shows the bi-variate Pearson correlation coefficients between the selected variables used in the study. The correlation coefficients are based on the data from 27 commercial banks for the period of 2009 to 2018. The dependent variable is nonperforming loan (NPL in percentage). The independent variables are deprived sector lending (DSL in percentage), bank size (total assets in NPR. Million), market coverage (MC in number of branches operating all over the country), capital adequacy ratio (CAR in percentage), and net interest income (NII in NPR. Million).

\begin{tabular}{|c|c|c|c|c|c|c|c|}
\hline \multicolumn{8}{|c|}{ Pearson's Correlations } \\
\hline & NPL & DSL & BS & MC & OS & CAR & NII \\
\hline NPL & 1 & & & & & & \\
\hline DSL & -0.004 & 1 & & & & & \\
\hline BS & $.142 *$ & $.479 * *$ & 1 & & & & \\
\hline MC & $.379 * *$ & $.520 * *$ & $.621 * *$ & 1 & & & \\
\hline OS & $.560 * *$ & $.230 * *$ & $.367 * *$ & $.744 * *$ & 1 & & \\
\hline CAR & $-.462 * *$ & 0.077 & $-.335 * *$ & $-.200 * *$ & $-.380 * *$ & 1 & \\
\hline NII & $.225^{* *}$ & $.454 * *$ & $.950 * *$ & $.669 * *$ & $.433 * *$ & $-.325^{* *}$ & 1 \\
\hline \multicolumn{8}{|c|}{ * Correlation is significant at the 0.05 level (2-tailed). } \\
\hline \multicolumn{8}{|c|}{ ** Correlation is significant at the 0.01 level (2-tailed). } \\
\hline
\end{tabular}

Source: Writer's own calculation using SPSS V.23.

This table shows that the NPL has a positive relation with BS, MC, OS, and NII and negative relation with DSL and CAR. This result indicates that the higher the ratio of DSL, the lower would be the NPL and vice-versa. Likewise, the results also show that the larger the bank size, the higher would be the NPL. Similarly, the larger the market share, the higher would be the NPL as there is positive relation with MC. The result shows that there is a positive correlation of NPL with OS which is a dummy variable of OS. The result indicates that public banks have higher NPL in comparison to private banks. Likewise, a result also shows that there is a negative correlation with CAR which indicates higher the CAR, the lower would be the NPL. Similarly, a result also indicates higher the NII, the higher would be the NPL as there is a positive correlation of NPL with NII. The above result also shows the high causality between NII and BS followed by NII and MC.

\subsection{Regression Analysis}

This section presents a robustness test by using the OLS regression model. The regression of nonperforming loans on deprived sector loans and other bank-specific control variables. This study does not include macroeconomic variables in the model. The regression results of NPL on DSL and other bank-specific control variables have been presented in table 7.

Table 7. Estimated relationship between NPL and DSL along with other variables

This table shows the regression results of panel ordinary least square regressions for the sample of 27 commercial banks with 130 observations for the period of 2009 to 2018. The model is, $(N P L)_{i t}=\beta_{0}+\beta_{1}(D S L)_{i t}+\beta_{2}(B S)_{i t}+\beta_{3}(M C)_{i t}$ $+\beta_{4}(O S)_{i t}+\beta_{5}(C A R)_{i t}+\beta_{6}(N I N)_{i t}+\phi_{i t}+\varepsilon_{i t}$ The dependent variable is nonperforming loan (NPL in percentage). The independent variables are deprived sector lending (DSL in percentage), bank size (BS as total assets in NPR. Million), market coverage (MC in number of branches operating all over the country), capital adequacy ratio (CAR in percentage), net interest income (NII in NPR. Millions) and $\phi$ is the fixed effects of banks and years of observation. 


\begin{tabular}{|c|c|c|c|c|c|c|c|c|}
\hline & 1 & 2 & 3 & 4 & 5 & 6 & 7 & 8 \\
\hline \multirow[t]{2}{*}{ Constant } & $1.97 * * *$ & $(-3.719)^{*}$ & $5.343 * *$ & 3.379 & $9.597 * * *$ & $14.656 * * *$ & $13.633 * * *$ & $9.597 * * *$ \\
\hline & (3.779) & $(-1.698)$ & $(2.302)$ & $(1.576)$ & $(4.215)$ & $(5.201)$ & $(5.025)$ & $(4.215)$ \\
\hline \multirow[t]{2}{*}{ DSL } & -0.007 & -0.166 & $(-0.455)^{* * *}$ & $(-0.262)^{* * *}$ & -0.12 & -0.088 & -0.041 & -0.12 \\
\hline & $(-0.068)$ & $(-1.341)$ & $(-3.836)$ & $(-2.340)$ & $(-1.113)$ & $(-0.821)$ & $(-0.404)$ & $(-1.113)$ \\
\hline \multirow[t]{2}{*}{$\mathrm{BS}$} & & $0.599 * * *$ & -0.278 & -0.083 & $(-0.614) * * *$ & $(-1.972) * * *$ & $(-1.946) * * *$ & $(-0.614) * * *$ \\
\hline & & $(2.676)$ & $(-1.187)$ & $(-0.386)$ & $(-2.761)$ & $(-3.886)$ & $(-3.832)$ & $(-2.761)$ \\
\hline \multirow[t]{2}{*}{$\mathrm{MC}$} & & & $0.29 * * *$ & 0.003 & $0.009 *$ & 0.006 & & $0.009 *$ \\
\hline & & & $(7.546)$ & $(0.503)$ & $(1.861)$ & $(1.321)$ & & $(1.861)$ \\
\hline \multirow[t]{2}{*}{$\mathrm{OA}$} & & & & $4.399 * * *$ & $2.977 * * *$ & $2.830 * * *$ & $3.419 * * *$ & $2.977 * * *$ \\
\hline & & & & $(7.089)$ & $(4.713)$ & $(4.533)$ & $(7.787)$ & (4.713) \\
\hline \multirow[t]{2}{*}{ CAR } & & & & & $(-0.111)^{* * *}$ & $(-0.113) * * *$ & $(-0.107)^{* * *}$ & $(-0.111) * * *$ \\
\hline & & & & & $(-5.884)$ & $(-6.081)$ & $(-5.927)$ & $(-5.884)$ \\
\hline \multirow[t]{2}{*}{ NII } & & & & & & $1.327 * * *$ & $1.434 * * *$ & \\
\hline & & & & & & (2.967) & $(3.254)$ & \\
\hline Year foxed effect & Yes & Yes & Yes & Yes & Yes & Yes & Yes & Yes \\
\hline Firm fixed effect & Yes & Yes & Yes & Yes & Yes & Yes & Yes & Yes \\
\hline Observations & 262 & 262 & 262 & 262 & 262 & 262 & 262 & 262 \\
\hline Adjusted $\mathrm{R}^{2}$ & 0.00 & 0.019 & 0.194 & 0.323 & 0.401 & 0.419 & 0.417 & 0.401 \\
\hline F-Value & 0.50 & 3.58 & 21.886 & 32.111 & 35.972 & 32.357 & 38.368 & 35.972 \\
\hline
\end{tabular}

Source: Writer's own calculation using SPSS V.23.

Notes:

1. Figures in parentheses are $t$-values.

2. The asterisk (***), (**) and (*) sign indicates that the results are significant at 0.01, 0.05and 0.1 level of significance respectively.

3. Dependent variable is NPL.

The regression result shows that the beta coefficient of DSL is negative. It indicates that higher the ratio of deprived sector lending lower would be the NPL. But the result is not significant individually. However, the result of equation (3) and (4) illustrates that there is a significant impact on NPL. This result shows the assumption that NBA and related stakeholders have been arguing as DSL is the cause of NPL for a commercial bank is not true. The major concern of commercial banks is they cannot invest such an amount of money in more profitable customers with high-interest rates. The implementation of direct lending to the deprived sector defiantly leads to high operational cost and procedural time-consuming in a small amount of file which might impact on overall profit but it does not lead on NPL.

This model also incorporates bank size, market coverage of the banking operation, ownership structure, and risk-weighted capital adequacy ratio, and net interest income as a control variable which are the influencing factor for NPL. The regression results are presented in above table 5.3.1.

This study tries to investigate the movement of NPL and DSL. For the explanation of DSL movement and its impact on NPL, I use model II. The regression results of the movement of DSL and its impact on NPL have been presented in table 8.

Table 8. Estimated relationship between change in NPL and DSL along with other variables

This table shows the regression results of panel ordinary least square regressions for the sample of 27 commercial banks with 130 observations for the period of 2009 to 2018. The model is, $(\Delta N P L)_{i t}=\beta_{0}+\beta_{1}(\Delta D S L)_{i t}+\beta_{2}(\Delta B S)_{i t}+$ $\beta_{3}(\Delta M C)_{i t}+\beta_{4}(O S)_{i t}+\beta_{5}(\Delta N I N)_{i t}+\phi_{i t}+\varepsilon_{i t}$ The dependent variable is change in nonperforming loan ( $\triangle N P L$ in percentage) from year t to $t-1$. The independent variables are change in deprived sector lending ( $\triangle D S L$ in percentage), bank size ( $\triangle B S$ total assets in NPR. Million), market coverage ( $\triangle M C$ in number of branches operating all over the country), capital adequacy ratio (CAR in percentage), net interest income (NII in NPR. Millions) and $\phi$ is the fixed effects of banks and years of observation.

\begin{tabular}{|c|c|c|c|c|}
\hline \multicolumn{5}{|c|}{ Dependent Variable is Change in Nonperforming loan } \\
\hline \multicolumn{5}{|c|}{ Outcome: Change in Nonperforming loan } \\
\hline & 1 & 2 & 3 & 4 \\
\hline Constant & -0.026 & 0.011 & -0.025 & 0.011 \\
\hline & $(-0.172)$ & $(0.069)$ & $(-0.167)$ & $(0.068)$ \\
\hline$\triangle \mathrm{DSL}$ & $(-0.295)^{* * *}$ & $(-0.459) * * *$ & $(-0.461) * * *$ & $(-0.461)^{* * *}$ \\
\hline & $(-2.729) * * *$ & $(-3.300)$ & $(-3.323)$ & $(-3.261)$ \\
\hline$\Delta \mathbf{B S}$ & & -0.634 & -0.647 & -0.625 \\
\hline & & $(-1.575)$ & $(-1.609)$ & $(-1.510)$ \\
\hline$\Delta \mathbf{M C}$ & & & & 0.001 \\
\hline
\end{tabular}




\begin{tabular}{|l|r|r|r|r|}
\hline & & & & $(0.095)$ \\
\hline$\Delta$ NII & & $1.011^{* *}$ & $1.029^{* *}$ & $(2.267)$ \\
\hline & & $(2.223)$ & Yes & $(1.907)$ \\
\hline Year fixed effect & Yes & Yes & Yes & Yes \\
\hline Firm fixed effect & Yes & Yes & 262 & Yes \\
\hline Observations & 262 & 262 & 0.04 & 262 \\
\hline Adjusted R & 0.02 & 0.04 & 4.46 & 0.03 \\
\hline F-Value & 7.45 & 3.45 & 2.75 \\
\hline
\end{tabular}

Source: Writer's own calculation using SPSS V.23.

Notes:

1. $\quad$ Figures in parentheses are $t$-values.

2. The asterisk $(* * *),(* *)$ and $(*)$ sign indicates that the results are significant at $0.01,0.05$ and 0.1 level of significance respectively.

3. Dependent variable is NPL.

The regression result shows the beta coefficient of $\triangle \mathrm{DSL}$ is significantly negative with $\triangle \mathrm{NPL}$. This indicates that the higher the growth of DSL, the lower would be NPL growth rate and vice-versa. This shows that the influence of DSL is very low as per this empirical result. In this model test result, other control variables have insignificant impacts on change in NPL.

If you compared the result of Model I there was an insignificant impact of DSL on NPL. However, from second model result indicates that there is negative impact on movement. It means that if banks use deprived sector lending as a portfolio investment, a policy burden will help to reduce NPL. The regression result of other bank-specific variables impact on NPL has been presented in table 5.3.2.

\section{Summary and Conclusion}

This study investigates the empirical impact of deprived sector lending on the nonperforming loans of commercial banks in Nepal using secondary data collected from 27 commercial banks from the fiscal year 2009 to 2018 with 262 observations. The study has employed the OLS regression method for the robustness test of the results. The study establishes an empirical relationship between deprived sector lending and nonperforming loan of commercial banks which is the major motivation of this study.

The basic regression result shows that the beta coefficient of DSL is negative. It indicates that the higher the ratio of deprived sector lending lower would be the NPL and vice-versa. Similarly, this study also examines the DSL movement's impact on NPL. The result shows that the beta coefficient of $\triangle \mathrm{DSL}$ is significantly negative with $\triangle \mathrm{NPL}$. This indicates that the higher the growth of DSL lower would be NPL growth rate and vice-versa. This shows that the influence of DSL is very low as per this empirical result.

Overall, the study shows there is an inverse relationship between deprived sector lending and nonperforming loan of banks. The result indicates that the remark of commercial bank's on the deprived sector lending policy of NRB is not true. The operational cost might increase with direct lending to the deprived sector and that leads to a decrease in the bank's overall profit. However, increasing deprived sector lending does not increase bank nonperforming loans. This study has established empirical relation and directional movement between DSL and bank's NPL. But, this study does not examine the causal relationship between DSL and NPL. There might be a causal relationship between them. Thus, further study can be extended more rigorously by including current lacking and covering more factors of deprived sector lending and bank's credit risks.

\section{References}

Aynalem, S. (2018). Factor Affecting Nonperforming Loans in Commercial Bank of Ethiopiya. Master's Thesis. Retrieved from www.ssrn.com

Berger, A. N., \& DeYoung, R. (1997). Problem Loans and Cost Efficiency in Commercial Banks. Journal of Banking and Finance, 21(6), 849-870. https://doi.org/10.1016/S0378-4266(97)00003-4

Bhatia, A., Mahajan, P., \& Chander, S. (2012). Determinants of Profitability of Private Sector Banks in India. Journal of Commerce and Accounting Research, 1(2), 14-22.

Bruton, G. D., Khavul, S., \& Chavez, H. (2011). Micro-lending in Emerging Economics: Building a new line of Inquiry from the Ground Up. Journal of International Business Studies, 42(5), 718-739. https://doi.org/10.1057/jibs.2010.58

Canova, F., \& Ciccarelli, M. (2013). Panel Vector Auto Regression: a survey. Working paper number 1507. European 
Central Bank. https://doi.org/10.1108/S0731-9053(2013)0000031006

Deokar, B., \& Shetty, S. L. (2013). Priority Sector Credit: Disappointment after Nair Committee Report. Economic and Political Weekly, 48(16), 55-57.

Dhar, S., \& Bakshi, A. (2015). Determinants of Loan Losses of Indian Banks: A Panel Study. Journal of Asia Business Study, 9(1), 17-32. https://doi.org/10.1108/JABS-04-2012-0017

Furfine, C. (2001). Bank Portfolio Allocation: The Impact of Capital Requirements, Regulatory Monitoring and Economic Conditions. Journal of Finance Services Research, 20(1), 33-56. https://doi.org/10.1023/A:1011147609099

Gambacorta, L., \& Chavan, P. (2019). Bank Lending and Loan Quality: an Emerging Economy Perspective. Empirical Economics, 57(1), 1-29. https://doi.org/10.1007/s00181-018-1436-5

Jouida, S. (2018). Bank Capital Structure, Capital Requirements and SRISK Across Bank Ownership Types and Financial Crisis: Panel VAR Approach. Review of Quantitative Finance and Accounting, 53(1), 295-352. https://doi.org/10.1007/s11156-018-0750-5

Kadanda, D., \& Raj, K. (2018). Non-performing Assets (NPAs) and It's Determinants: a Study of Indian Public Sector Banks. Journal of Social and Economic Development, 20(2), 193-212. https://doi.org/10.1007/s40847-018-0068-0

Kaur, S. (2012). Non-performing Assets of Indian Commercial Banks. SUMEDHA Journal of Management, 1(3), 39-55. https://doi.org/10.15373/22778179/APR2014/201

Lokare, S. M. (2014). Reemerging Stress in Asset Quality of Indian Banks: Macro-financial Linkages. RBI working Paper Number 3.

Oli, S. K. (2018). Impact of microfinance Institutions on Economic Growth of Nepal. Asian Journal of Economic Modelling, 6(2), 98-109. https://doi.org/10.18488/journal.8.2018.62.98.109

Pepur, S., \& Tripovic, M. (2017). Credit Risk and Bank Profitability: Case of Croatia. Finance in Central and Southeastern Europe. Contributions to Economics. Springer, Cham. https://doi.org/10.1007/978-3-319-64662-6_8

Reddy, Y. (2004). Credit Policy, Systems and Culture. Reserve Bank of India Bulletin, March, 2004.

Sharma, M. (2005). Problem of NPA and Its Impact on Strategic Banking Variables. Finance India, 19(3), 593-967.

Sims, C. A. (1980). Macroeconomics and reality. Econometrica, 48(1), 1-48. https://doi.org/10.2307/1912017

Sinha, S. (2012). Public and Private Sector Banks: Convergence in Performance. Economic and Political Weekly, 47(20), 25-30.

Sufian, F., \& Habibullah, M. H. (2009). Bank Specific and Macroeconomic Determinants of Bank Profitability: Empirical Evidence from the China Banking Sector. Frontiers of Economics in China, 4(2), 274-291. https://doi.org/10.1007/s11459-009-0016-1

Tang, Y., Chen, H., Wang, B. Chen, M., Chen, M., \& Yang, X. (2009). Discriminant Analysis of Zero Recovery for China's NPL. Journal of Applied Mathematics and Decision Sciences, 2009(6), 1-16. https://doi.org/10.1155/2009/594793

Verma, R., \& Bodla, B. S. (2006). Determinants of Profitability of Banks in India: A Multivariate Analysis. Journal of Service Research, 6(2), 75-89.

Note:

NRB directives number 17/067 including other (http://www.nrb.org.np)

NRB monetary policy 2018/19 including other (https://mof.gov.np)

\section{Copyrights}

Copyright for this article is retained by the author(s), with first publication rights granted to the journal.

This is an open-access article distributed under the terms and conditions of the Creative Commons Attribution license which permits unrestricted use, distribution, and reproduction in any medium, provided the original work is properly cited. 